\title{
Study on Shock Disinfection in a Fire Extinguishing Water Supply System
}

\author{
Kun Xiang ${ }^{1}$, Pan Geng ${ }^{2,3}$, Xuan Sun ${ }^{1}$, Shasha Yuan ${ }^{1}$, Peng Du ${ }^{1,2}$ and Xing Li ${ }^{2, *}$ \\ 1 Institute of Building Fire Research, China Academy of Building Research, Beijing 100013, China; \\ xk0807@163.com (K.X.); 13911365611@126.com (X.S.); yuanshasha1988@126.com (S.Y.); \\ 18810503116@163.com (P.D.) \\ 2 Department of Urban Construction, Beijing University of Technology, Beijing 100124, China; \\ 18701521556@163.com \\ 3 Beijing Municipal Commission of Housing and Urban-Rural Development, Beijing 101100, China \\ * Correspondence: lixing@bjut.edu.cn
}

Citation: Xiang, K.; Geng, P.; Sun, X.; Yuan, S.; Du, P.; Li, X. Study on Shock Disinfection in a Fire Extinguishing Water Supply System. Water 2021, 13, 2967. https://doi.org/10.3390/ w13212967

Academic Editor:

Helvi Heinonen-Tanski

Received: 26 September 2021

Accepted: 18 October 2021

Published: 21 October 2021

Publisher's Note: MDPI stays neutral with regard to jurisdictional claims in published maps and institutional affiliations.

Copyright: (C) 2021 by the authors. Licensee MDPI, Basel, Switzerland. This article is an open access article distributed under the terms and conditions of the Creative Commons Attribution (CC BY) license (https:// creativecommons.org/licenses/by/ $4.0 /)$.

\begin{abstract}
The biofilms generated in a fire extinguishing water supply system can cause corrosion and a reduction in the water supply capacity; thus, degrading the system performance. To mitigate microbial corrosion, appropriate disinfection measures are necessary. In this study, the secondary addition of chlorine is employed to investigate the kinetics of chlorine decay, and shock disinfection is applied to investigate the removal efficiency of corrosion bacteria, and the microbial composition of a biofilm on the pipe wall was also clarified. The results show that the residual chlorine content in the secondary chlorination process was directly correlated with the decay rate of residual chlorine and the corrosion rate of the pipe wall. Additionally, the chlorine impact disinfection method could reduce the electrochemical corrosion phenomenon of the pipe wall. When the concentration of chlorine was $3 \mathrm{mg} / \mathrm{L}$, the removal rate of corrosion bacteria was higher in $60 \mathrm{~min}$ than in $30 \mathrm{~min}$. Specifically, most of the bacteria were inactivated in $60 \mathrm{~min}$ and the biofilm was severely damaged. Shock disinfection could significantly inactivate all microflora in the biofilm; the relative abundances of microflora varied significantly, while the change of microflora at the phylum level was insignificant. This study can provide theoretical support for the secondary addition of chlorine and shock disinfection in a fire extinguishing water supply system.
\end{abstract}

Keywords: fire extinguishing water supply system; stainless steel pipeline; microbial corrosion; biofilm; shock disinfection

\section{Introduction}

Failures in firefighting and delays in fire suppression result in serious consequences, of which $81.5 \%$ are due to the lack of a fire extinguishing water source and imperfect fire extinguishing water supply facilities [1,2]. Additional important reasons for failures in firefighting include difficulty in opening fire hydrants, blockage of the self-spraying nozzles, and an underperforming flow of self-spraying nozzles [3]. Because a water-based fire extinguishing system is only used when there is a fire, the commonly used metal pipelines that are always filled with water are exposed to severe corrosion and scaling. Compared with a pipeline composed of other materials, the pipelines composed of stainless steel are safer, more reliable, and have a longer service life and; thus, are more suitable for fire extinguishing systems. However, stainless steel pipelines are also exposed to corroding [4].

Previous studies of microbial population and microbial corrosion of water supply pipeline mainly focus on the municipal water supply pipeline [3,5]. Although the water for the fire extinguishing system comes from the municipal water supply network, the fire extinguishing system is only opened during firefighting or maintenance. Thus, there are still some differences in the state of the pipe network and water demand between 
two water supply systems. Due to the large number of users and accessories used in the municipal water supply system, the circulation time of the water in this system is short, while the water in the fire extinguishing water system only comes out once a fire breaks out, or when the end water test devices are repaired at ordinary times. Therefore, the water in the pipe network of the fire water system is static most of the time.

After the water stays in the pipeline for a long time, the residual chlorine in the municipal water decays to a very low concentration, resulting in the breeding of microorganisms in the pipeline. These microorganisms adhere to the pipe wall, resulting in biofilms and pipeline scale and; thus, blocking self-spraying nozzles in the system. As a result, a reduction in the water delivery capacity of the fire extinguishing pipeline occurs. In addition, the stainless steel pipeline interface may be exposed to Microbially Induced Corrosion (MIC), resulting in water leakage and difficulty in opening the fire hydrant [6]. Therefore, it is necessary to clean and disinfect the fire extinguishing pipeline system regularly to mitigate pipeline corrosion [7].

The secondary addition of a disinfectant in the pipeline system can remove the biofilm on the pipe wall and microorganisms in water [8]; thus, effectively mitigating pipeline corrosion. An appropriate increase in the disinfectant concentration during the secondary disinfection process is conducive to improving the sterilization effect. However, the longterm use of a high concentration of disinfectant in the fire extinguishing system may cause corrosion of the pipeline wall. The method of shock disinfection adds a higher dose of disinfectant over a short time during cleaning or maintenance, so that the biofilm on the pipe wall can be removed rapidly and the microorganisms can be inactivated efficiently. Various studies on the sterilization effect and biofilm destruction of chlorine shock disinfection, which can effectively mitigate biofilm formation and the microbial corrosion of pipe walls, have been reported [9]. At present, chlorine shock disinfection is used in fire extinguishing systems to inactivate microorganisms, but there are few studies on the control of pipeline corrosion $[10,11]$.

In this study, municipal water was used as the water supply of a fire extinguishing system. The correlations between the residual chlorine content after a secondary chlorination and the removal rate of corrosion bacteria as well as the corrosion potential and corrosion rate of the stainless steel pipe wall are studied. The effects of the chlorine shock disinfection process on microbial corrosion and the necessity of chlorine shock disinfection are explored, and changes in the characteristics of the biofilm and biological community on the pipe wall are characterized. This study provides support for the application of chlorine shock disinfection technology in fire extinguishing systems.

\section{Methods}

\subsection{Sample Water and Testing Method}

Municipal water collected from tap water was used in the fire extinguishing system. The water was injected into an isothermal stainless steel incubator in the volume of $50 \mathrm{~L}$ at $16{ }^{\circ} \mathrm{C}$ for $0-60 \mathrm{~d}$, and its $\mathrm{pH}$ value was adjusted to 7.0. The incubator connected with stainless steel pipeline was set as a fire water tank, and the sample water, pipeline, and biofilm were collected to analyze water quality and microbial characteristics.

The residual chlorine, corrosion potential, corrosion rate, and removal rate of corrosion bacteria were regularly analyzed after the secondary chlorination using a simulated pipeline system. After 30-60 min of chlorine shock disinfection, the biofilm on the pipe wall was sampled to investigate the morphology and distribution of the microbial community.

\subsection{Analysis Methods}

\subsubsection{Electrode and Analysis of Residual Chlorine}

The polarization curve was measured with an electrochemical workstation (CHI604D, Shanghai Chenhua, Shanghai, China). The reference electrode was a saturated calomel electrode and the counter electrode was a platinum electrode. The concentration of residual 
chlorine (chloride ion, $\mathrm{Cl}^{-}$) was determined by a portable residual chlorine meter (Q-CL501, Shenzhen Qingshijie, Shenzhen, China) with an accuracy of $0.01 \mathrm{mg} / \mathrm{L}$.

\subsubsection{Detection of Corrosion Rate}

Pretreated stainless steel coupons were weighed, acid cleaned (using nitric acid of $0.10 \mathrm{mg} / \mathrm{L}$ ), etched, rinsed, and weighed again. The average corrosion rate was determined by the coupon weight loss method according to the mass change before and after the coupon corrosion every 3 days. The corrosion rate of pipeline could be calculated by [10]:

$$
\mathrm{V}=87,600(\mathrm{~m} 1-\mathrm{m} 2) / \mathrm{D} \cdot \mathrm{S} \cdot \mathrm{T}
$$

where $\mathrm{V}$ is the corrosion rate $(\mathrm{mm} / \mathrm{g}) ; \mathrm{S}$ is the surface area of the pipe wall $\left(\mathrm{cm}^{2}\right)$; $\mathrm{D}$ is the density of pipe wall $\left(\mathrm{g} / \mathrm{cm}^{3}\right) ; \mathrm{m} 1$ is the mass of the pipe wall that is not corroded $(\mathrm{g}) ; \mathrm{m} 2$ is the mass of the pipe wall after corrosion $(\mathrm{g})$; $\mathrm{T}$ is the corrosion time (h).

\subsubsection{Detection of Removal Rate of Corrosion Bacteria}

The bacteria attached to the surface of the coupon were rinsed with sterile ultrapure water and wiped from the pipe wall of stainless steel pipeline five times with two or three sterilized cotton swabs. Afterwards, the cotton swabs were immersed in $10 \mathrm{~mL}$ sterilized ultrapure water and placed in an ultrasonic cleaner at a temperature of $20^{\circ} \mathrm{C}$ and a frequency of $40 \mathrm{kHz}$ for $20 \mathrm{~min}$. The corrosion bacteria with a high probability to cause the corrosion of pipeline, denoted as corrosion bacteria, and the detailed methods of counting corrosion bacteria, total and heterotrophic bacteria, were followed according to previous research. After diluting the mixed water samples 10 times in turn, the hot sterilized medium was poured into the Petri dish. After the medium was cooled and solidified, $100 \mu \mathrm{L}$ of bacterial solution was absorbed by sterilized straw and placed on the solid medium. After the plate was coated, the bacteria were placed upside down in a constant temperature incubator at $22{ }^{\circ} \mathrm{C}$ for 7 days and the colony count was performed, in unit of $\mathrm{CFU} / \mathrm{cm}^{2}$.

The removal rate of bacteria can be calculated by [8]:

$$
S=-\ln (N 1 / N 0)
$$

where $S$ is the removal rate of bacteria, $N 0$ is the number of bacteria before disinfection, and $N 1$ is the number of bacteria after disinfection.

\subsubsection{Biofilm Morphology Observation}

After fixing the pipe wall sample and metal spraying on its surface, the morphology of biofilm was observed for the scanning electron microscopy (SEM) measurement by using a field emission scanning electron microscope (Nova nano450, FEI, Hillsboro, OR, USA). The observation proportion of FEI microscope was 1000 times, and the detailed operation method was followed according to previous research [12].

\subsubsection{Metagenomic Analysis}

The biological flora was detected by the $16 \mathrm{~S}$ rDNA sequencing method and metagenomic sequencing technology, which was analyzed by MiSeq Sequencing instrument (MiSeq, Illumina, State of California, USA) in the standard mode of $2 \times 300$, and their detailed operation method was described by Jin et al. [13]. The biofilm on the pipe wall was sampled and the biological flora was enriched. Specifically, the biological flora was mixed with pure water, and $4 \mathrm{~mL}$ of mixed water was taken out to add into a sterilized $2 \mathrm{~mL}$ centrifuge tube in two operations. The sample was centrifuged at $104 \mathrm{rpm}$ for $3 \mathrm{~min}$ at room temperature. The supernatant was discarded and the centrifuge tube was inverted on absorbent paper for one minute until no liquid came out. A total of $0.2 \mu \mathrm{m}$ polycarbonate membrane was used to filter the centrifuged sample; then, the membrane was put into a test tube filled with sterile water. After fully mixing, the DNA of microorganisms in the 
water samples was extracted. The extracted total microbial DNA was used as a template to amplify the V3-V4 region of $16 \mathrm{~S}$ rDNA of bacterial metagenomic DNA, whose universal primers fused with MiSeq sequencing platform were 341F and 805R. Finally, the sample underwent sequencing analysis with a sequencer.

\section{Results and Discussion}

\subsection{Corrosion Control Characteristics of Secondary Chlorination}

\subsubsection{Trend of Residual Chlorine Decay}

As depicted in Figure 1, the attenuation trend of residual chlorine decay reduced when the secondary chlorine concentration was $0.12,0.25,0.5,1,3$, and $5 \mathrm{mg} / \mathrm{L}$. As observed, the correlation between the chlorine concentration and residual chlorine concentration was significant. The residual chlorine concentration of a chlorine concentration less than $1.0 \mathrm{mg} / \mathrm{L}$ was already extremely low after $16 \mathrm{~h}$, while that of a 3-5 mg/L chlorine concentration was still 1.35-1.75 mg/L after $60 \mathrm{~h}$, indicating that the residual chlorine concentration of the high concentration chlorine was higher and the residual chlorine maintenance time was longer. Additionally, with the increase in the secondary chlorine concentration from 0.12 to $5 \mathrm{mg} / \mathrm{L}$ being added, the consumption rate of the residual chlorine increased from 0.007 to $0.166 \mathrm{mg} / \mathrm{L} \mathrm{h}$, and the consumption rate of the residual chlorine at a chlorine concentration of 3-5 mg/L was $0.081-0.166 \mathrm{mg} / \mathrm{L} \mathrm{h}$, which was significantly higher than that at the $0.12-1 \mathrm{mg} / \mathrm{L}$ chlorine concentration $(0.007-0.043 \mathrm{mg} / \mathrm{L} \mathrm{h})$. This result highly correlated with Frateur et al.'s [14], who claimed that the increased consumption rate occurred because the chlorine at a higher concentration could react with both the biofilm and organic matter on the pipeline wall, and chlorine with an even higher concentration could cause corrosion of the pipe wall by reacting with the stainless steel.

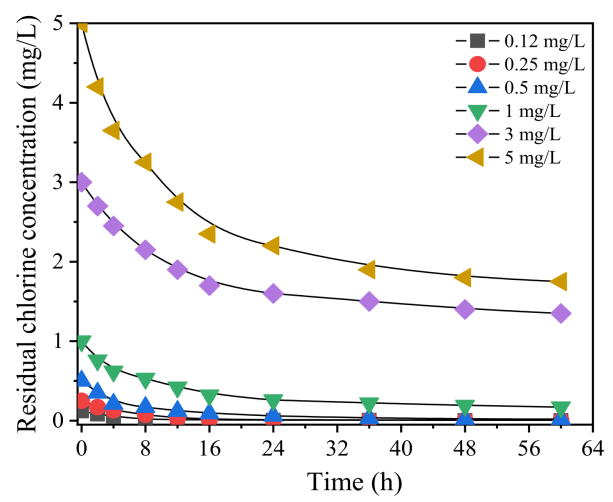

Figure 1. Correlation between initial chlorine concentration and residual chlorine concentration.

\subsubsection{Trend of Corrosion Potential}

As shown in Figure 2, the correlation between the disinfectant concentration and corrosion potential could be found. It could be found that when the chlorine concentration was $1 \mathrm{mg} / \mathrm{L}$, the corrosion potential showed a continuous downward trend, and the average corrosion potential during the $50-60 \mathrm{~d}$ period reached $-0.360 \mathrm{~V}$. When the chlorine concentration was $3 \mathrm{mg} / \mathrm{L}$, the downward trend of the corrosion potential was relatively stable, and the average corrosion potential during the $50-60 \mathrm{~d}$ period was $-0.233 \mathrm{~V}$, which was $35.3 \%$ lower than that at a chlorine concentration of $1 \mathrm{mg} / \mathrm{L}$. At a chlorine concentration of $5 \mathrm{mg} / \mathrm{L}$, the corrosion potential first increased slowly and then rapidly. During the 0-20 d period, the corrosion potential was stable in the range of $-0.165 \pm 0.011 \mathrm{~V}$, and then rapidly increased to $-0.428 \mathrm{~V}$ during the $50-60 \mathrm{~d}$ period, which was $18.9 \%$ higher than that a chlorine concentration of $1 \mathrm{mg} / \mathrm{L}$. This result correlated with the study of Landoulsi [14], who claimed that biofilms cause the raise in free corrosion potential. As observed, the concentration of the disinfectant had a significant impact on the trend of corrosion potential, which might be related to electrochemical corrosion and disinfection [15]. As the hydraulic retention time increased, the residual chlorine at a chlorine concentration of $1 \mathrm{mg} / \mathrm{L}$ 
was consumed, but there was still a residual biofilm attached to the pipe wall. As a result, the microbial corrosion effect could continue to increase the corrosion potential. As the chlorine concentration increased, the corrosion potential decreased. When the chlorine concentration was $3 \mathrm{mg} / \mathrm{L}$, the biofilm was completely destroyed and the microbial removal rate was high. Hence, the corrosion potential remained low. When the chlorine concentration was $5 \mathrm{mg} / \mathrm{L}$, the excessive residual chlorine caused electrochemical corrosion of the pipe wall, resulting in a significant increase in the corrosion potential [16].

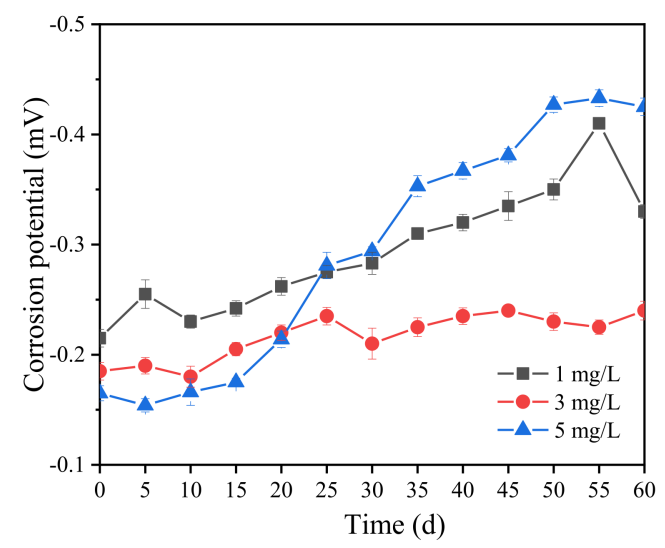

Figure 2. Correlation between initial chlorine concentration and corrosion potential.

\subsubsection{Trend of Corrosion Rate}

As shown in Table 1, the correlation between disinfectant concentration and corrosion rate was investigated. When the chlorine concentration was 1,3 , and $5 \mathrm{mg} / \mathrm{L}$, the average corrosion rate during a 3-6 d period was $0.054-0.057 \mathrm{~mm} / \mathrm{a}$, and the difference of corrosion rate was negligible. The average corrosion rate during a $6-15 \mathrm{~d}$ period was $0.064-0.069 \mathrm{~mm} / \mathrm{a}$, and the corrosion rate showed a significant upward trend. Compared with the chlorine concentrations of 1 and $5 \mathrm{mg} / \mathrm{L}$, the average corrosion rate at $3 \mathrm{mg} / \mathrm{L}$ decreased by 10.22 and $15.20 \%$, respectively. There was a significant correlation between the chlorine concentration and corrosion rate. The damage of the biofilm at a chlorine concentration of $1 \mathrm{mg} / \mathrm{L}$ was not significant, and the rate of Microbially Induced Corrosion (MIC) caused by the residual biofilm remained high. With a chlorine concentration of $3 \mathrm{mg} / \mathrm{L}$, the damage of the biofilm was significant and the MIC rate was reduced. A chlorine concentration of $5 \mathrm{mg} / \mathrm{L}$ effectively inactivated microorganisms and mitigated MIC. However, the high content of residual chlorine could cause the electrochemical corrosion of the pipe wall and significantly increase the corrosion rate. The MIC rate responding to the weight reduction in the pipeline resulted from a biological effect and electrochemical action. As observed, the disinfection process could effectively inactivate microorganisms of biofilm on the pipe wall and significantly reduce the MIC rate, but a high concentration of disinfectant could also cause the electrochemical corrosion of the pipe wall. Therefore, an optimal shock disinfection should inactivate the microorganisms on the pipe wall without causing severe electrochemical corrosion.

As shown in Figure 3, a schematic of the corrosion process of a pipe wall during chlorine disinfection could be found. As observed, the biofilm on the pipe wall destroyed the passivation film on the pipe wall by producing metabolites, which reduced the corrosion resistance of the pipe wall and accelerated the cathodic depolarization process, resulting in pitting corrosion of the pipe wall. With a chlorine concentration of $1 \mathrm{mg} / \mathrm{L}$, the residual chlorine concentration was low, and the MIC of the pipe wall was severe. The residual chlorine concentration was high when the chlorine concentration was higher than $3 \mathrm{mg} / \mathrm{L}$, but the corrosion rate was faster when the chlorine concentration was $5 \mathrm{mg} / \mathrm{L}$. The increased corrosion rate occurred primarily because the chlorine of the high concentration would damage the passivation film surface and cause severe electrochemical corrosion. 
Table 1. Correlation between initial content of residual chlorine and corrosion rate.

\begin{tabular}{|c|c|c|c|c|c|c|}
\hline $\begin{array}{c}\text { Chlorine } \\
\text { Concentration } \\
(\mathrm{mg} / \mathrm{L})\end{array}$ & & & & & & \\
\hline Time (d) & $\begin{array}{c}\text { Weight } \\
\text { Variation (mg) }\end{array}$ & $\begin{array}{c}\text { Corrosion Rate } \\
(\mathrm{mm} / \mathrm{a})\end{array}$ & $\begin{array}{c}\text { Weight } \\
\text { Variation }(\mathrm{mg})\end{array}$ & $\begin{array}{c}\text { Corrosion Rate } \\
(\mathrm{mm} / \mathrm{a})\end{array}$ & $\begin{array}{c}\text { Weight } \\
\text { Variation }(\mathrm{mg})\end{array}$ & $\begin{array}{c}\text { Corrosion Rate } \\
(\mathrm{mm} / \mathrm{a})\end{array}$ \\
\hline 3 & 4.1 & 0.052 & 3.7 & 0.051 & 4.5 & 0.055 \\
\hline 6 & 10.8 & 0.056 & 8.9 & 0.053 & 12.5 & 0.059 \\
\hline 10 & 17.7 & 0.067 & 12.2 & 0.058 & 19.8 & 0.069 \\
\hline 15 & 26.8 & 0.073 & 20.4 & 0.062 & 28.9 & 0.078 \\
\hline 20 & 39.5 & 0.075 & 26.2 & 0.066 & 42.3 & 0.081 \\
\hline
\end{tabular}

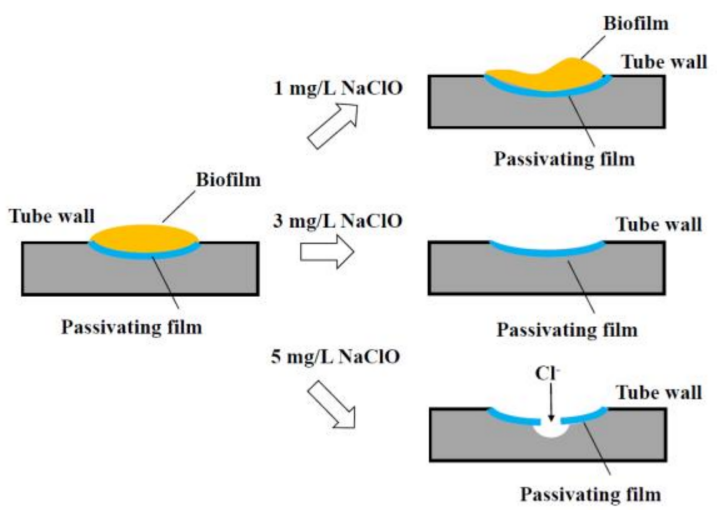

Figure 3. Schematical diagram of chlorine disinfection.

\subsection{Microbial Removal Efficiency of Shock Disinfection}

\subsubsection{Removal Effect of Corrosion Bacteria}

As shown in Figure 4, the correlation between the chlorine concentration and removal rate of corrosion bacteria in the biofilm on the pipe wall during shock disinfection could be found. As observed, the removal rate of corrosion bacteria increased continuously with chlorine concentrations of 1,3 , and $5 \mathrm{mg} / \mathrm{L}$. For chlorine concentration shock disinfection times of 180, 90, and $60 \mathrm{~min}$ for the concentrations of 1,3 , and $5 \mathrm{mg} / \mathrm{L}$, respectively, the removal rates of corrosion bacteria were $1.39,1.51$, and $1.73 \mathrm{lg}$, respectively. The corrosion bacteria were a typical bacteria species causing MIC of the metal pipe wall, which included iron-oxidizing and iron-reducing bacteria, sulfate-reducing bacteria, and firmicutes. The trend of the corrosion bacteria quantity during shock disinfection was similar to that of the total bacteria and heterotrophic bacteria count (HPC) [15]. Additionally, the removal rate of corrosion bacteria was affected by both the disinfectant concentration and shock disinfection time. When the shock disinfection time remained constant, the removal rate of corrosion bacteria positively correlated with chlorine concentration. A high concentration of disinfectant required a shorter disinfection time to effectively inactivate the microorganisms of the biofilm on the pipe wall, while a low concentration required a longer disinfection time to achieve the same removal effect. When the concentration of disinfectant remained constant, there was also a positive correlation between the removal rate of corrosion bacteria and the disinfection time. As the disinfection continued, the residual chlorine consumption gradually increased and the removal rate of corrosion bacteria reduced. As shown in Figures 2 and $4,3 \mathrm{mg} / \mathrm{L}$ was a suitable disinfectant concentration for the mitigation of both the MIC rate and chemical corrosion of the pipe wall [17]. 


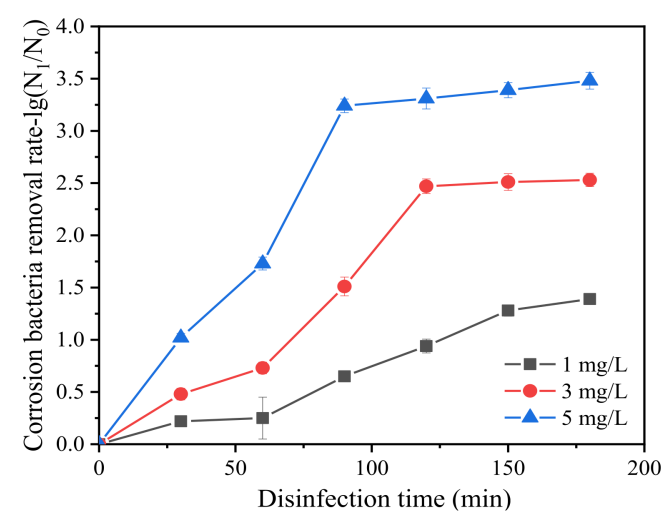

Figure 4. Correlation between chlorine concentration and corrosion bacteria removal.

\subsubsection{Morphological Changes of Biofilm}

The biofilm characteristics on the stainless steel pipe wall with a chlorine concentration of $3 \mathrm{mg} / \mathrm{L}$ are shown in Figure 5. As observed, the biofilm on the pipe wall was thick and dense before shock disinfection. This was because the water in the pipe had a long retention time, and the organic matter in the water was conducive to bacterial proliferation, resulting in a significant biofilm on the pipe wall. After 30 min of shock disinfection, some sections of the biofilm shrank and fell off the surface, and a few sections of pipe wall were exposed. Pores and cracks appeared in the biofilm, but its surface structure was still dense, indicating that the destruction of the biofilm by the chlorine shock disinfection was relatively low. The thickness and morphology of the biofilm changed significantly after 60 min of shock disinfection. The biofilm presented a discrete small block structure with a smooth surface and most of the pipe wall was exposed, indicating that chlorine shock disinfection severely damaged the biofilm on the pipe wall [17].
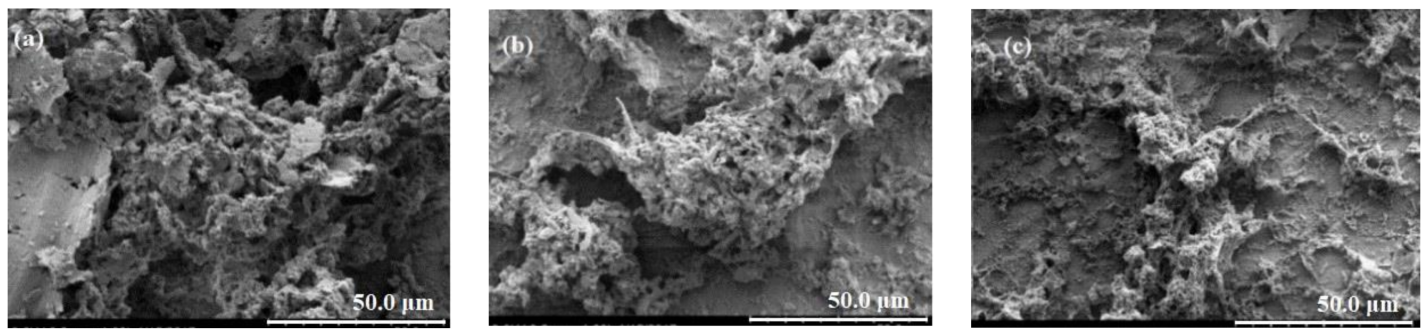

Figure 5. Morphology of biofilm on pipe wall after different durations of shock disinfection. (a) Disinfection for 0 min. (b) Disinfection for $30 \mathrm{~min}$. (c) Disinfection for $60 \mathrm{~min}$.

\subsubsection{Composition of Bacterial Community before and after Disinfection Shock Treatment}

As shown in Figure 6, the distribution characteristics of the biofilm flora on the pipe wall could be found, in which the sample coverage reached $99 \%$, and the Shannon index and Simpson index was 4.62 and 0.04 , respectively, indicating a high diversity of the biofilm flora on the pipe wall. As observed, the abundance of Proteobacteria was 64.8\%, of which the $\alpha, \beta, \gamma$, and $\delta$ Proteobacteria accounted for $39.6,24.1,4.3$, and $4.8 \%$ of the Proteobacteria, respectively. The Proteobacteria was mainly composed of corrosion bacteria and sulfate-reducing bacteria, which could easily cause an increased MIC of the pipe wall [18]. Additionally, the abundance of Bacteroidetes was 3.97\%, in which the bacterial solution produced by Flavobacteria could adhere to the surface of the pipe wall together with corrosion bacteria, and scale on the pipe wall was observed, resulting in a reduced water transmission capacity of the pipeline [19]. 
(a)

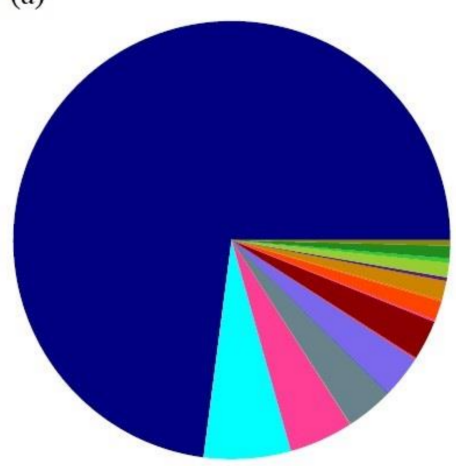

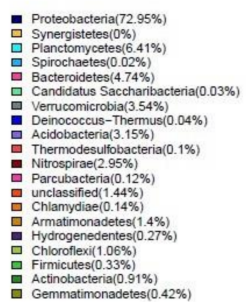

(b)

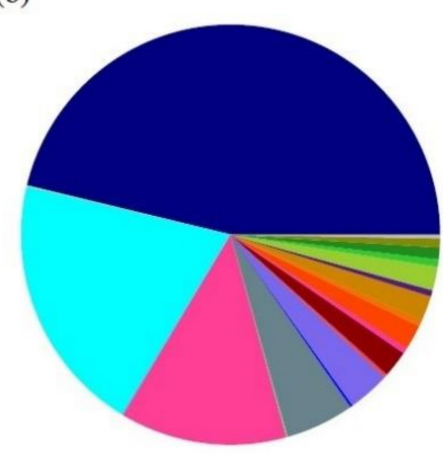

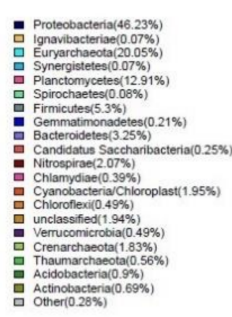

Figure 6. Distribution of bacteria in biofilm. (a) Before shock disinfection. (b) After 60 min of shock disinfection.

After 60 min of shock disinfection, no significant difference in the species of bacteria at the phylum level was observed, while the abundance changed significantly. The abundance of Proteobacteria decreased to $46.23 \%$, and the abundance of $\alpha$ and $\beta$ Proteobacteria decreased from $39.60 \%$ and $24.14 \%$ to $17.3 \%$ and $13.24 \%$, respectively, indicating that the chlorine shock disinfection preferred the removal of $\alpha$ and $\beta$ Proteobacteria; thus, effectively mitigating the MIC rate. After chlorine shock disinfection, the abundance of Planctomycetes and Firmicutes increased from $12.68 \%$ and $3.45 \%$ to $12.91 \%$ and $5.30 \%$, respectively. This can be attributed to the high chlorine resistance of these bacteria such that they can survive a high chlorine concentration [20]. Firmicutes could promote the proliferation of microorganisms and accelerate the MIC of the pipe wall. Hence, chlorine shock disinfection could significantly inactivate various flora in the biofilm, although the extent of the removal differed. Indeed, the dominant flora that corroded the pipe wall was effectively inactivated and inhibited.

\section{Conclusions}

In this study, the attenuation of residual chlorine in the process of secondary chlorination disinfection of a stainless steel pipeline in a fire extinguishing system and the correlation between the residual chlorine content and pipe wall corrosion rate were investigated. The removal rate of corrosion bacteria, morphological changes of the biofilm on the pipe wall, and distribution of microbial communities under chlorine shock disinfection were determined. The main conclusions were as follows:

1. The chlorine concentration of secondary chlorination had a positive correlation with the residual chlorine content and a negative correlation with the decay rate of residual chlorine. The decay rate of residual chlorine at a chlorine concentration of $0.12-1 \mathrm{mg} / \mathrm{L}$ was $0.007-0.043 \mathrm{mg} / \mathrm{L} \mathrm{h}$, while the corrosion rate of the pipe wall caused by microorganisms remained relatively high. At a chlorine concentration of $3 \mathrm{mg} / \mathrm{L}$, the decay rate of the residual chlorine was $0.081 \mathrm{mg} / \mathrm{L} \mathrm{h}$, the corrosion potential of the pipeline wall was -0.18 to $-0.23 \mathrm{mV}$, and the corrosion rate was relatively low. At a chlorine concentration of $5 \mathrm{mg} / \mathrm{L}$, the decay rate of the residual chlorine was $0.166 \mathrm{mg} / \mathrm{L} \mathrm{h}$, the corrosion potential reached $-0.42 \mathrm{mV}$, and significant electrochemical corrosion was observed.

2. There was a significant positive correlation between the chlorine concentration in shock disinfection and the removal rate of corrosion bacteria. At a chlorine concentration of $1 \mathrm{mg} / \mathrm{L}$ and a disinfection time of $180 \mathrm{~min}$, the removal of corrosion bacteria in the biofilm on the pipe wall was limited. The removal effect of corrosion bacteria was enhanced at shock disinfection treatments of $3 \mathrm{mg} / \mathrm{L}$ for $90 \mathrm{~min}$ or $5 \mathrm{mg} / \mathrm{L}$ for $180 \mathrm{~min}$. At a chlorine concentration of $3 \mathrm{mg} / \mathrm{L}$, the biofilm only partially fell off the pipe wall after $30 \mathrm{~min}$ of shock disinfection, and the biofilm was severely damaged after $60 \mathrm{~min}$ of shock disinfection. Shock disinfection could significantly inactivate the various flora in the biofilm, but the degree of removal differed with the type of 
flora. At a chlorine concentration of $3 \mathrm{mg} / \mathrm{L}$ and a disinfection time of $60 \mathrm{~min}$, the abundance of $\alpha$ and $\beta$ Proteobacteria of the biofilm decreased from $39.60 \%$ and $24.14 \%$ to $17.3 \%$ and $13.24 \%$, respectively. The dominant bacteria that corroded the pipeline wall were effectively inactivated and inhibited.

\begin{abstract}
Author Contributions: K.X. and P.G. were responsible for the experimental work, X.S. and S.Y. supervised the laboratory work, P.D. and X.L. led the research. All authors have read and agreed to the published version of the manuscript.

Funding: This work was supported by the Research and Engineering Application of Fire Safety Assessment Technology for Large Traffic Building (grant number 20190111330730002).
\end{abstract}

Conflicts of Interest: The authors declare no conflict of interest.

\title{
References
}

1. Luo, J.H.; Liang, H.; Yan, L.J.; Ma, J.; Yang, Y.L.; Li, G.B. Microbial community structures in a closed raw water distribution system biofilm as revealed by 454-pyrosequencing analysis and the effect of microbial biofilm communities on raw water quality. Bioresour. Technol. 2013, 148, 189-195. [CrossRef] [PubMed]

2. Yin, L.; Xu, D.K.; Yang, C.G.; Chen, X.B.; Yang, K. Ce addition enhances the microbially induced corrosion resistance of Cu-bearing 2205 duplex stainless steel in presence of sulfate reducing bacteria. Corros. Sci. 2021, 179, 109141. [CrossRef]

3. Okeola, O.G.; Sule, B.F. Evaluation of management alternatives for urban water supply system using multicriteria decision analysis. J. King Saud Univ. Eng. Sci. 2012, 24, 19-24. [CrossRef]

4. Sobral, J.; Ferreira, L. Maintenance of fire sprinkler systems based on the dynamic assessment of its condition. Process. Saf. Prog. 2016, 35, 84-91. [CrossRef]

5. Shuang, Q.; Zhang, M.; Yuan, Y. Node vulnerability of water distribution networks under cascading failures. Reliab. Eng. Syst. Saf. 2014, 124, 132-141. [CrossRef]

6. Mahajan, S.; Chhibber, R. Elevated temperature molten salt corrosion study of SS304L austenitic boiler steel. Sadhana-Acad. Proc. Eng. Sci. 2020, 45, 199. [CrossRef]

7. Chen, H.Y.; Wei, Z.Y.; Sun, G.Y.; Su, H.; Liu, J.Q.; Hu, B.L.; Zhou, X.Y.; Lou, L.P. Formation of biofilms from new pipelines at both ends of the drinking water distribution system and comparison of disinfection by-products formation potential. Environ. Res. 2020, 182, 109150. [CrossRef] [PubMed]

8. Zhu, L.; Chen, T.; Xu, L.; Zhou, Z.C.; Feng, W.Q.; Liu, Y.; Chen, H. Effect and mechanism of quorum sensing on horizontal transfer of multidrug plasmid RP4 in BAC biofilm. Sci. Total. Environ. 2019, 698, 134236. [CrossRef] [PubMed]

9. Treman, B.F.; Gregory, B.S.; Mccormick, N.E.; Gao, Y.H.; Gora, S.; Anaviapik-Soucie, T.; L'Herault, V.; Gagnon, G.A. Manganese increases lead release to drinking water. Environ. Sci. Technol. 2019, 53, 4803-4812. [CrossRef] [PubMed]

10. Xu, C.; Zhang, Y.; Cheng, G.; Zhu, W.S. Localized corrosion behavior of 316L stainless steel in the presence of sulfate-reducing and iron-oxidizing bacteria. Mat Sci Eng A-Struct. 2007, 443, 235-241. [CrossRef]

11. Lan, C.M.; Tuerhan, M.; Liu, C.P. Monitoring of chloride-induced corrosion in steel rebars. Corros. Eng. Sci. Technol. 2018, 53, 601-610. [CrossRef]

12. Zhenbang, P.I. Electrochemical studies on carbon steel corrosion induced by mixed colonies. Corros. Sci. Technol. Prot. 2002, 14, 165-166.

13. Jin, J.; Wu, G.; Guan, Y. Effect of bacterial communities on the formation of cast iron corrosion tubercles in reclaimed water. Water Res. 2015, 71, 207-218. [CrossRef] [PubMed]

14. Landoulsi, J.; Kirat, K.E.; Richard, C.; Feron, D.; Pulvin, S. Enzymatic approach in microbial-influenced corrosion: A review based on stainless steels in natural waters. Environ. Sci. Technol. 2008, 42, 2233-2242. [CrossRef] [PubMed]

15. Frateur, I.; Deslouis, C.; Kiene, L.; Levi, Y.; Tribollet, B. Free chlorine consumption induced by cast iron corrosion in drinking water distribution systems. Water Res. 2006, 33, 1781-1790. [CrossRef]

16. Starosvetsky, J.; Starosvetsky, D.; Pokroy, B.; Hilel, T.; Armon, R. Electrochemical behavior of stainless steels in media containing iron-oxidizing bacteria (IOB) by corrosion process modeling. Corros. Sci. 2008, 50, 540-547. [CrossRef]

17. Simoes, L.C.; Simoes, M. Biofilms in drinking water: Problems and solutions. RSC Adv. 2013, 3, 2520-2533. [CrossRef]

18. Lautenschlager, K.; Hwang, C.; Liu, W.T.; Boon, N.; Koster, O.; Vrouwenvelder, H.; Egli, T.; Hammes, F. A microbiology-based multi-parametric approach towards assessing biological stability in drinking water distribution networks. Water Res. 2013, 47, 3015-3025. [CrossRef] [PubMed]

19. Douterelo, I.; Sharpe, R.L.; Boxall, J.B. Influence of hydraulic regimes on bacterial community structure and composition in an experimental drinking water distribution system. Water Res. 2013, 47, 503-516. [CrossRef] [PubMed]

20. Li, N.; Li, X.; Shi, Z.Y.; Fan, X.Y.; Zhou, Z.W. Response of high-, mid- and low-abundant taxa and potential pathogens to eight disinfection methods and their interactions in domestic hot water system. Sci. Total. Environ. 2020, 749, 141440. [CrossRef] [PubMed] 